\title{
SOCIAL AND ENVIRONMENTAL ASPECTS OF COURTYARDS IN CYPRUS VERNACULAR ARCHITECTURE
}

A B S S T R A C T

Central courtyards emerged in many civilizations of the world. Cyprus was no exception as courtyards formed important architectural features throughout the centuries in the residential architecture of the island. The erection of dwellings attached to each other, the need for a private outdoor protected space due to the introverted character of societies, as well as the climatic conditions, i.e.warm Mediterranean climate, led to a widespread use of the courtyard in nearly all traditional residences of the island in the last two centuries. Apart from vernacular architecture, courtyards appeared in earlier historic periods and, in some cases, they were found to be used in the residential architecture of more recent decades. This paper presents an analytical study of the social and environmental aspects of courtyards in the vernacular dwellings of Cyprus. The research underlines the role of the courtyard as an important social gathering area, as well as a microclimate regulator in the residences. Moreover, it highlights its bioclimatic significance in enhancing the integration of nature's elements into the design and overall architectural concept of the dwelling. 


\section{INTRODUCTION}

Courtyards, as the main open space of many dwellings, constituted important features in residential architecture throughout antiquity in Cyprus as well as in many other civilizations. Houses were designed with rooms of various functions surrounding the courtyards and were organized in association with these yards as the life of the occupants evolved around them. The important role played by the courtyard was due to social parameters as well as to the climatic conditions of the area that offered occupants a protected area suitable for outdoor activities throughout the year. Thus, the courtyard always held a special, functional, social and environmental role within a residence. John Reynolds ${ }^{1}$ describes courtyards as special places that are outside yet almost inside, open to sky, usually in contact with the earth, but surrounded by rooms. According to Suha $\mathrm{Okzan}^{2}$ the natural elements of the courtyard, i.e. earth beneath and sky above, ensure its direct contact with nature. This study presents an overall view of all the different factors related to the courtyards of vernacular architecture found in different areas of Cyprus (plains, mountains) underlining their social, as well as their environmental significance.

\section{HISTORIC BACKGROUND}

Historically, courtyards have been the most popular feature in residential architecture all over the world, in different climatic regions, found in practically all civilizations. ${ }^{3}$ Paul Oliver ${ }^{4}$ maintains that courtyard houses have an ancient history: Very early examples were excavated at Kahun in Egypt (5000 years old), as well as at Chaldean City of Ur (2000 BC). Similar residential typologies were also found in Minoan Crete (1600 BC). According to many researchers, the courtyard-type house is most probably associated with the arid climates of Middle Eastern countries. However, the form remains equally prevalent in all the countries and climatic regions of the world. According to Craig Hinrichs, time, civilizations and climatic conditions seem to have an insignificant effect on the courtyard-style house. The dwellings of many different civilizations bear evidence to the fact that the courtyard house form is rather timeless in the history of architecture. In the same vein, Atillio Petruccioli ${ }^{6}$ argues that climate is not the underlying reason for the courtyard houses. However, it becomes a generic typology in hot and dry climate environments. Apart from the climatic and functional significance of the specific plan typology, its cultural relevance is of equal importance. It seems that the initial appearance of courtyard houses around the world was most probably associated with cultural, social and functional factors and diachronically this typology prevailed due to its social, functional as well as environmental significance. 
In Cyprus, courtyard houses were widespread throughout all periods of antiquity. ${ }^{7}$ The first almost regular rectangular structures with courtyards appeared in the Early Bronze Age (2300-2100 BC) with rooms arranged in an L-shape plan around an open area (Figure1a). Structures with rooms in a U-shape arranged around courtyards were initially found in a series of houses excavated in Alhambra-Mouttes dated to the Middle Bronze Age (1900-1650 $\mathrm{BC})$. Of particular interest is one house complex found in Kalopsida (Figure1b) comprised of twelve rooms arranged around two courtyards which dates back to the same period. This constitutes the first example of a complex incorporating two courtyards excavated in the island. The existence of a semi-open space situated in front of a closed room which served as the transition space between the open yard and the different rooms of the house is also worth mentioning. Built arrangements, incorporating courtyards, can be observed in houses in many archaeological sites dated to the Late Bronze Age (1650-1050 BC) (Figure1c,d) and later to the Classical (475-325 BC) (Figure1e), Hellenistic (325-30 BC) and Roman (30 BC-4 ${ }^{\text {th }}$ century AC) (Figure 1f) periods. More specifically, structures with two open-to-sky spaces are very widespread in Roman architecture. The Roman open-air spaces were probably inspired by the Greek peristyle houses or the Etruscan courtyard houses. In early Christian and Byzantine Times, houses with courtyards of a relatively small scale were found in many areas of the island.

During the $19^{\text {th }}$ and early $20^{\text {th }}$ century, the courtyard-house type represented the most common type of vernacular dwelling both in urban and rural settlements. Courtyards form essential parts of the vernacular architecture of Cyprus and therefore appear in the majority of traditional buildings all over the island. The

(a)

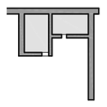

(b)

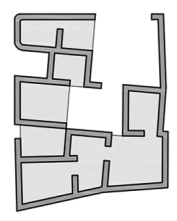

(c)

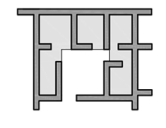

(d)

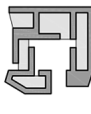

(e)

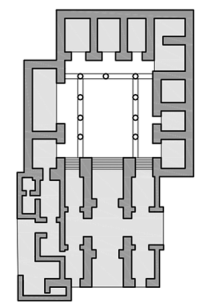

(f)

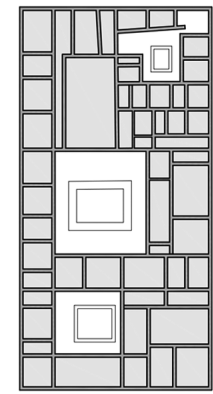

Figure 1. Courtyard houses in Cyprus throughout different periods of antiquity: (a) Alhambra-Mouttes and (b) Kalopsida, Middle Bronze Age, 1900-1650 BC; (c) Pyla-Kokkinokremos and (d) Kalavasos-Ayios Dhimitrios, Late Bronze Age, 1650-1050 BC; (e) Vouni, Classical Period, 475-325 BC; (f) Paphos, House of Dionyssos, Roman Period 30 BC- 4th century AC. (Source: Plan layouts prepared by the authors). 
arrangement of the courtyard presents a series of alterations and incorporates many design innovations related to spatial configuration of the settlement's building material and especially of its location in different topographies (coastal areas, plains, mountains). The existence of different arrangements confirms the adaptation of the courtyard houses in different climates and landscapes. At the same time, semi-open spaces (called iliakoi) were attached to the closed rooms and were in direct contact with the courtyard offering additional protected space for everyday activities.

The courtyard typology, and thus the creation of an open-air space in the centre of each plot, was also enhanced by the urban configuration and in particular by the erection of houses attached to each other, following a continuous building system. This configuration ensured satisfactory ventilation and lighting to the rooms arranged around the central yard. In Cyprus, the courtyard house type was a direct response to the social preference for privacy and seclusion of family life, while it also constituted an essential functional space for household and social activities.

According to a number of studies ${ }^{8}$ the central courtyard constitutes a vital feature of vernacular architecture in the countries of the East-Mediterranean region (Egypt, ${ }^{9}$ Syria, Greece), as the main source of daylight and natural ventilation for interior spaces. ${ }^{10}$ The utmost significance of courtyards as an anthropological archetype is not made evident in the Mediterranean and Middle East area exclusively; it has also been recorded in other climatic contexts such as tropical and hot-arid climates. According to Ghaffarian Hoseini et al., ${ }^{11}$ courtyards in Malay vernacular architecture were designed for household activities, as well as for relaxation. The study deduced that the concept of privacy and the optimal use of spaces form the most significant socio-cultural values. At the same time, natural ventilation and daylighting are considered to be the most significant environmental values within Malay houses. In the same vein, Broach et al. ${ }^{12}$ highlight the contribution of courtyards as a climate responsive building design strategy of vernacular architecture in Nepal. Moreover, the study underlines courtyards' positive contribution to the lighting performance of traditional buildings, allowing the penetration of daylight into nearly all inner rooms of the dwelling in very dense traditional settlement structures.

The building regulations implemented by the British Colonial Rule, and adopted by the Republic of Cyprus in the $20^{\text {th }}$ century, introduced the detached urban system with an empty space around the plot, which led to significant changes in the arrangement of the urban centres. During mid $20^{\text {th }}$ century, architectural 
production in the island was mainly based on the conditions of the structural forms of modern-movement architecture, i.e. the generalized use of reinforced concrete and on the transfer of the design principles of the international style in architecture. The erection of houses with a central courtyard was rather difficult due to the limitations of the plot size and the above-mentioned regulations. Nevertheless, in a limited number of cases, central yards continue to play a principal role in modern-movement residential architecture of Cyprus. ${ }^{13} \mathrm{~A}$ conscious effort to integrate specific spatial characteristics of vernacular architecture, such as courtyards, is made in houses designed by the modernist architect Neoptolemos Michaelides. ${ }^{14}$

\section{COURTYARDS IN VERNACULAR DWELLINGS. SOCIAL AND BIOCLIMATIC SIGNIFICANCE

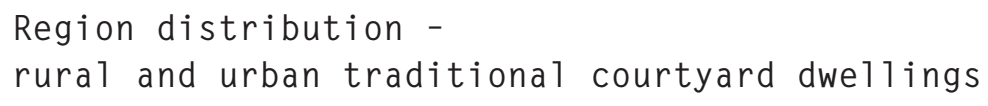

Courtyard houses appear in nearly all regions of Cyprus following different arrangements and having various sizes depending on social and climatic factors. The island can be divided into different areas ${ }^{15}$ : Karpasia, Mesaoria, Kerynia, Pendadaktylos and Akamas according to the settlements configuration. In some areas, such as the Karpasia region, yards have a large size and irregular shape and are surrounded by low boundary walls. Thus, the outdoor area of the house constitutes the natural boundary of the fields. Similar examples of yards not defined by strong building elements can be found in remote villages of Cyprus such as the Akamas area where yards become part of the surroundings. Courtyards surrounded by high boundary walls and buildings can be found in the densely populated regions of Karpasia. This enclosed type of courtyard presents a different conception compared to the above mentioned one, offering more privacy. In this case, the occupants of the house define the area required for their private life and work and make it inaccessible for strangers by building a high wall. In this area, they can spend their free time privately with their family, thus escaping from common activities and isolating themselves.

In the Mesaoria plain, open-air space of houses is limited due to the more dense built character of the region. In the Mesaoria, courtyards are smaller in size and enclosed by a high wall. The rooms are located at the back of the plot with only a few exceptions of them built along the road with the yard located at the back. In the Mesaoria region, organising free space is associated with the closed and introverted character of the area. It is also noted that, safety is a major factor in this region which impacts on the structure of the settlements. 
In Troodos mountainous area, the size and significance of the yard is rather limited due to geomorphological reasons. Houses, in certain settlements, such as Kakopetria face the street with large balconies on their first floor. In the Kyrenia and Pentadaktylos region, the expression of open spaces has multiple manifestations as a result of the great social and economic differences of the inhabitants. In the densely populated areas of Kyrenia, high surrounding walls are common. The area of the yard is often small and takes the shape of an enclosed courtyard.

Based on a general overview of the courtyard type of rural dwellings in Cyprus, one observes that the rooms in rural settlements are most commonly located at the boundaries of the plot and more often at the back, leaving the yard at the front. More rarely, rooms are built along the road leaving the yard at the back. In urban areas on the other hand, courtyards are usually located at the back of the plots as all the buildings are projected on the road boundaries to underline the social status of their inhabitants. According to Danilo, ${ }^{16}$ the typology of the urban centre houses of Nicosia changed diachronically and evolved from rural to urban house types. Initially, the arrangements were similar to those followed in rural areas with buildings situated at the back of a plot of a large size with the yard at the front. The urbanization of the city led to the fragmentation of land, and thus to a limited space for each building and to a dense built environment. As the street layout began to play the most important role in urban development, the main building volumes were located with direct contact and access to the street leaving open spaces (courtyards) at the back. Gradually, additions to the building volumes led to the creation of a continuous frontage in the street (Figure 2). Building volumes expanded in one, or two, wings surrounding a courtyard from two or three sides, creating more complex building typologies.

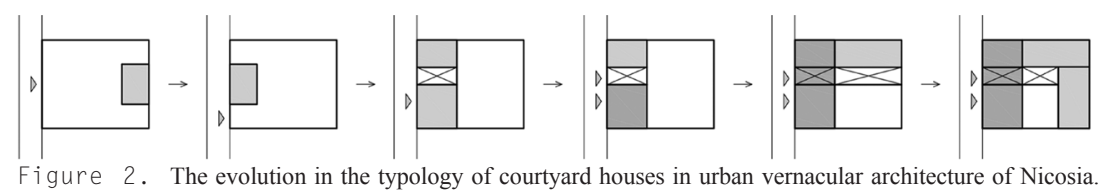
(Source: Source Danilo [16], edited by the authors)
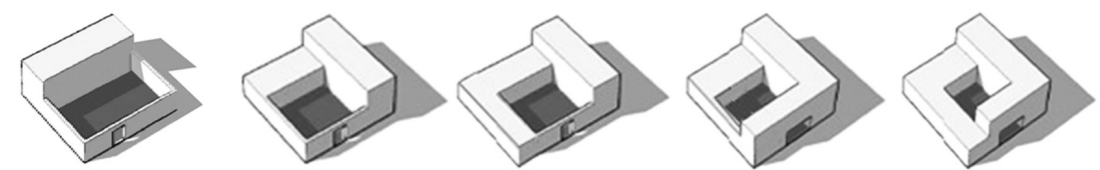

Figure 3. Different arrangements of indoor spaces around the courtyard in rural vernacular architecture. (Source: Prepared by University of Cyprus students, edited by the authors)

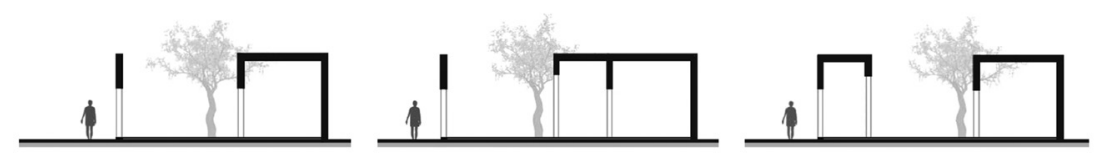

Figure 4. Different relations between the private spaces of the dwellings and the public domain of the settlement. (Source: Prepared by University of Cyprus students, edited by the authors) 
At the same time, urban traditional dwellings incorporate longitude semi-open spaces, called iliakos, located in direct contact to the courtyard attached to the building, offering private and environmentally comfortable transitional spaces for everyday activities. The entrance to the buildings was achieved through a central wide corridor or semi open space, called portico that led from the street to the courtyard through the main part of the dwelling. The limitations of land available led to the creation of two storey buildings, thus affecting the geometrical characteristic of the courtyards, i.e. height to width ratio. As a result of city urbanization, the rich diversity of original rural types of houses was replaced by new, more compact and typical urban building arrangements (Figure 2).

\section{Social and Environmental Aspects}

Form, shape and size have a key role in the analysis of courtyard houses. According to Amos Rapoport ${ }^{17}$ there is a differentiation between form and shape. Form refers to the fundamental organization of space (meaning and communication). In this context, the spatial organization and the relationships between the buildings domains are more fundamental than changes in shape. The analysis of courtyard houses shows that the shape of courtyards varies, from irregular to more rarely rectangular or square, whereas their form, which is the fundamental organization of space, follows the same principles. According to Sullivan Chip ${ }^{18}$ the size and scale of a courtyard may vary from very intimate to quite spacious. In any case, the courtyard creates an appropriate frame for natural lighting and ventilation.

The research showed that the shape of the courtyard in the vernacular architecture of Cyprus often changed to adapt to the topography, site restrictions, orientation and building functional requirements. These restrictions and requirements led to the creation of different shapes of the surrounding building volume such as I, L or U- shapes etc. Thus, the surrounding buildings occupy one, two or more sides of the courtyard (Figure 3). In some cases, building volumes appear peripherally along the sides of the plot and thus the courtyard acquires an enclosed character. In most cases, yards occupy approximately $25 \%$ of the plot, highlighting its significance.

In a number of vernacular houses, there is more than one courtyard with the inner one being more private. Conversely, in some cases, two different houses share a common courtyard. This arrangement was probably a result of later divisions of previously unified building complexes or may be explained by the close relationship between the owners of neighboring buildings. This phenomenon 
is more frequently observed in areas such as China and India where, in many cases, courtyards are considered to be communal open-air spaces, satisfying social and environmental aspects but not privacy. ${ }^{19}$

According to Nibedita $\operatorname{Das}^{20}$ the benefits of a courtyard house are psychosocial and cultural (privacy, introversion) as well as functional (accessibility, circulation). Detailed studies of courtyards showed that one of the primary advantages of courtyards is the provision of a sense of enclosure, as well as visual and acoustic privacy to the residents of the houses due to their inward form. Courtyards usually formed the initial private space where the visitor entered from the road thus ensuring gradual transition from open public to closed private space.

Securing the privacy of the courtyard is achieved by the use of physical elements. According to Amos Rapoport ${ }^{21}$ a settlement based on courtyard houses, is called the inside-out city and is fundamentally different from one where houses face outward to the street. Usually, the courtyard is defined by high walling in the cores of the settlements and by lower walling at the settlement's periphery. The private space of the dwellings is somehow related to the public domain of the settlement. According to Amos Rapoport ${ }^{22}$ the form of these linkages tends to vary and, as intermediate domains, is related to the sequence of outdoor spaces, e.g. streets, cul-de-sacs and porches, as well as to specific architectural elements, e.g. fences, gates and doors. The front door (xoporti) of rectangular or arched shape is often the only opening on the surrounding walls and constitutes the access from the public road to the courtyard of the dwelling. These front doors are quite wide to facilitate the entrance of wagons/carts and animals. These openings are sometimes directly linked to the semi-open spaces called iliakos or portico, which are often connected to the boundary walling (Figure 4).

The inward form of the house is also made evident by the limited number of openings towards the street. Moreover, the protection of the privacy of everyday life within the house is provided by the existence of a screening layer in the outer side of each opening. More specifically, this screening layer comprises of suitably placed small wooden bars which prevent undesirable visual connection from the outside surrounding to indoor spaces.

Courtyards, as the main circulation space of traditional dwellings, provide the main access to indoor spaces. Indoor spaces often have no direct communication between them due to lack of corridors within the houses. ${ }^{23}$ This configuration results from the compact form and the primary plan layout of traditional 
buildings. The location of the staircases leading to the first floor in the courtyards confirms their vital role in achieving circulation. The climatic conditions of the island, i.e. mild and arid dry climate, allow the residents to use both outside and inside spaces of the houses throughout the year. Additionally, the favorable climatic conditions enable the occupants to carry out a lot of their everyday activities in the open space of the traditional dwelling. A series of agricultural activities, as well as domestic functions, such as cooking, looming, weaving and washing, took place in the protected area of the courtyard. ${ }^{24}$ The courtyard is considered to be the most vital space of the traditional house. Moreover, it acts as a place of interaction, as the main place of social gathering for both residents and visitors (Figure 5). The courtyard can be thought of as an outdoor room since it is used as an extension of indoor spaces which are located in the perimeter of the courtyard and face towards it. At the same time, this particular configuration allows the direct relation between the indoor and outdoor spaces of the house.

The existence of semi-open spaces, i.e. iliakoi, porticos and covered balconies, in direct contact to courtyards is particularly common in vernacular dwellings. Semi-open spaces play an important functional role in the house, often placed in a perpendicular arrangement between the road and the courtyard constituting the main entrance hall, called portico, or located in front of indoor rooms, called iliakos, usually with a south-facing orientation, forming an outdoor sitting area. It is worth mentioning that the portico constitutes a transitory area where traditional occupants hold social interactions with society. The portico can thus, be considered as an extension of the public space and street life. Moreover, the portico allows cross ventilation and enhances the air flow within the traditional dwelling and thus has a bioclimatic significance. ${ }^{25}$ The iliakos, as a part both
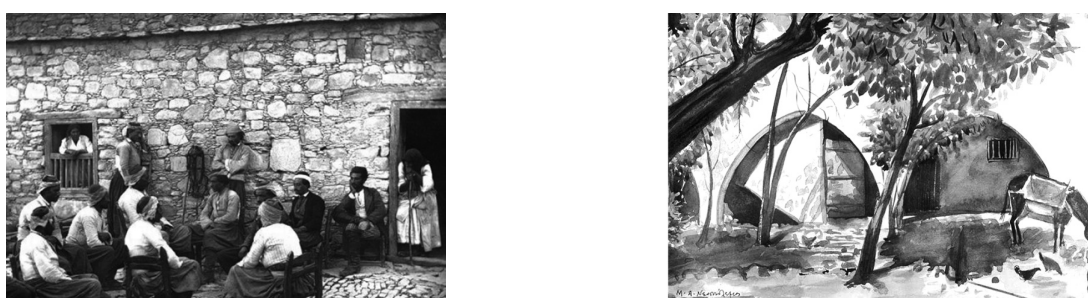

Figure 5. The courtyard as a space of (a) social gathering for both residents and visitors of the house (Source: Thomson, J., Through Cyprus with the Camera in the Autumn of 1878, London: Trigraph Limited, 1985) and (b) agricultural activities (Source: Hellenic Bank 1994 Calendar, Aquarelle by Neoptolemos Michaelides, entitled Courtyard in Kyrenia).
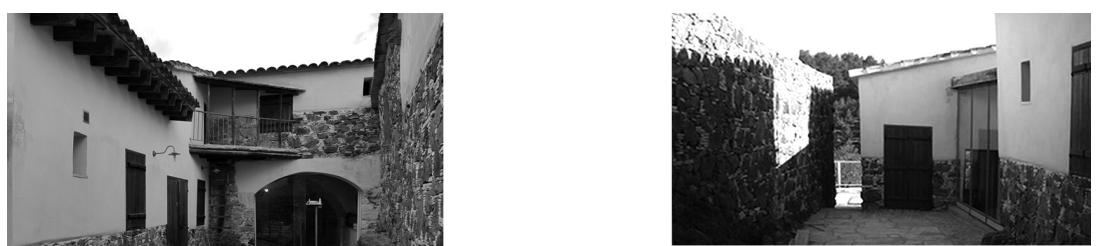

Figure 6. Central courtyard in a traditional house in the core of the rural settlement of Kapedes village, Nicosia. (Source: Authors' photograph collections) 
of the house and the courtyard and in direct relation with nature, also plays an important role in everyday life offering shading and minimizing direct sun radiation of the building envelope. Iliakoi also have a noteworthy bioclimatic behaviour and a positive contribution to the thermal comfort of occupants. The extensive use of outdoor spaces i.e. open and semi-open arrangements is directly related to the climatic conditions of the island and originates to the local social and cultural practices of the inhabitants of the island. ${ }^{26}$

The arrangement of a large number of openings in the building's walls around the courtyard helps towards the ventilation and the cooling of individual rooms. At the same time, smaller openings, called arseses, are located at a higher position in the exterior facades facing the street. Their high level position safeguards the privacy of everyday life and ensures cross ventilation of indoor spaces. Moreover, due to the difference in temperature and density of the air, arseres ensure the extract of hot air towards the external environment, (stack effect) contributing to the cooling of the spaces during the summer period. ${ }^{27}$

Courtyards, especially small-sized ones, enhance the urban heat effect as opposed to larger open air spaces (Figure 6). The southern insolation through the courtyard is very important in buildings where the plot orientation and/ or the surrounding built environment do not allow direct solar gains to the indoor areas. The floor materials, i.e. earth, clay, paving slabs and cobbles, as well as the surrounding courtyard walls, act as a heat storage increasing the temperature and affecting positively the thermal performance of the immediate environment of the residence during winter. The materials of the courtyards depend on the function of the courtyard, as well as on the socio-economic status of the inhabitants. Although in most of the cases floors are very simple, there are some excellent examples of decorated slab floors with circular or other rectilinear patterns. The roof of the ground floor rooms forms an extension of the courtyard, especially when a first floor exists.

The necessity of cooling the courtyards during the summer months is an imperative. The courtyard proportions and the dense fabric of traditional settlements, especially in complexes including two-storey buildings, block the penetration of solar radiation during summer and thus moderate undesirable high temperatures. The creation of shade in the courtyard for the most part of hot summer days maintains the temperature lower, in bearable levels (Figure 7). Additionally, trees and vegetation can be used to provide shade in the courtyards and in the spaces around it, when it is seasonally beneficial. Proper planting, usually in the form of deciduous trees and/or vines on pergolas ensures 
shading of the courtyard during summer. Deciduous trees and plants safeguard desirable direct solar gains during the winter months when trees and plans drop their leaves. Moreover, the protection from solar radiation as a result of rich vegetation secures the reduction of ground temperature (Figure 8). Evaporation from green leaves causes cooling of the air which becomes heavier and falls to the lower levels of the courtyard. At the same time, the hot air upraises outside the indoor spaces, drives outdoors through openings of the rooms and arches, and thus causes cool breezes in indoor spaces. During the summer period, night ventilation enables cool air to enter the indoor spaces through open windows and arches and thus removes the heat stored in the thermal mass of the building envelope during the day. The combination of shading and night cooling ventilation enables the reduction of temperatures of the indoor spaces and the courtyard, keeping them within acceptable limits, close to thermal comfort levels. ${ }^{28}$ Apart from shading and regulation of humidity levels, vegetation can also prevent, filter or divert the air flow, thus affecting the internal ventilation of buildings. ${ }^{29}$

The existence of water features in courtyards provides evaporation cooling which increases air humidity and enhances thermal comfort conditions during hot-dry days. The watering of plants in the courtyard is a widely used technique which has prevailed as a traditional activity since the beginning of the last century, for enhancing evaporation cooling. ${ }^{30}$

In addition to the improvement of the microclimatic conditions, courtyards ensure a pleasant view and visual comfort through proper vegetation ${ }^{31}$ and water features which contribute to the emotional and psychological state of

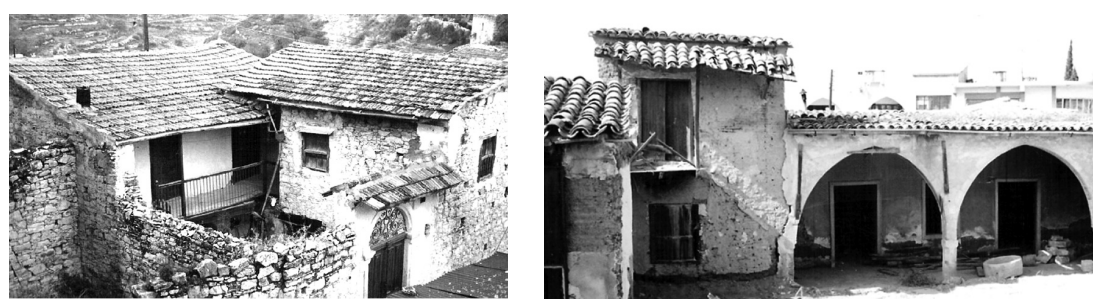

Figure 7. Courtyard houses in rural vernacular architecture in Cyprus. (Source: Authors' photograph collections)
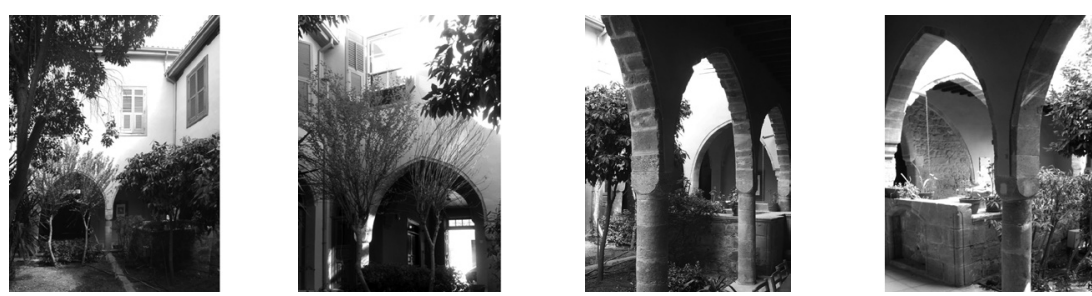

Figure 8. The courtyard in a traditional house in the centre of Nicosia. Indoor and semi-open spaces, i.e. iliakoi and portico, are located in the perimeter of the courtyard. (Source: Authors' photograph collections) 
the residents. ${ }^{32}$ The wide variety of passive devices integrated in the design of courtyards is in line with related literature that recognizes its environmental contribution and essential role as a microclimatic regulator. ${ }^{33}$

\section{CONCLUSIONS}

The investigation of vernacular houses underlines the great significance and the environmental contribution of the central courtyard. The courtyard has diachronically been the main feature of Cyprus residential architecture. In the last two centuries, the existence of courtyards has become more common in vernacular architecture as a result of the erection of buildings attached to each other. Thus, the courtyard constituted the main link of traditional residences to the external environment. Apart from its environmental benefits, the satisfactory dimensions of the courtyard provide several possibilities for its functional exploitation.

The existence of the courtyard in vernacular architecture offers a number of environmental benefits. Its function as a regulator of microclimatic conditions (heat gains, natural ventilation and lighting) provides favorable results during the summer and winter period. More specifically, the courtyard enables direct solar gains in the areas located around it. The absence of a built volume in the centre of the building secures the possibility of cross ventilation through air inlet and outlet openings. Moreover, the courtyard plays an important role in vernacular architecture of Cyprus, as it forms the main channel of natural lighting to the indoor spaces of the building. Courtyard houses are described by adaptability to the local climatic conditions. The existence of courtyards allows the integration of a series of passive design principles and thus ensures the optimal building's thermal performance approaching conditions closer to human comfort conditions. Courtyard houses cease to be passive receptors of the climatic conditions but are designed so as to function efficiently with the different environmental conditions. In this way, the sun and the wind are considered positive elements, defining the geometry and the overall composition of the houses.

The investigation showed that the prevalence of the courtyard house is not only related to its adaptation to the local climate conditions but also to the social and functional role that the specific space performs. Courtyard houses allow an efficient use of space, creating more compact forms of houses and a dense urban tissue, thus reducing the area of the settlement. The important role played by courtyards in the household organization through time in Cyprus is evidenced by their size, since they usually form the largest single area of the house. 
Courtyards, semi-open as well as indoor spaces comprise the basic elements of vernacular dwellings. Despite the diversity of the settlements layouts which results from the topographical and social factors that affect the urban fabric of the settlement, the preservation of the primary design elements of the archetypal residential building in Cyprus demonstrates the persistence in the old living habits for thousands of years. The connection with the environment and nature led to the creation of the courtyard house, thus satisfying the need of the occupants to be in direct contact and in harmony with the surrounding environment.

The present study demonstrates that the courtyard house provides significant social and functional benefits and, at the same time, it incorporates a series of environmentally-friendly design principles. The application of basic principles of bioclimatic design, referring both to heating and cooling strategies of the building envelope, as well as to strategies for the improvement of the microclimatic conditions of the immediate environment, provides adequate comfort conditions in the indoor spaces of traditional buildings. The deep understating of the environmental contribution, as well as the socio-cultural role of the courtyard in the vernacular architecture in Cyprus can inspire creative designs of contemporary architecture, leading to a sustainable development of the built environment.

John S. Reynolds, ed. Courtyards: Aesthetic, Social and Thermal Delight (New York: John Wiley, 2002).

Suha Özkan, "Foreword -Courtyard: A Typology that Symbolizes Culture," in: Courtyard Housing: Past, Present and Future, edited by Edwards Brian, Magda Sibley, Mohammad Hakmi and Peter Land (USA: Taylor and Francis, 2005), xiv-xvi.

Nibedita Das, Courtyards Houses of Kolkata: Bioclimatic, Typological and Socio-Cultural Study, Master of Architecture, Department of Architecture College of Architecture, Planning and Design, Kansas State University, Manhattan, Kansas, 2006.

Paul Oliver, Dwellings. The house across the world (Oxford: Phaidon Press Ltd., 1987).

Craig Hinrichs, "The Courtyard Housing Form as Traditional Dwelling," in: The Courtyard as dwelling, Traditional Dwellings and Settlements Working Paper Series, Volume VI, IASTE, WP06- 89 (Berkeley: Center for Environmental Design Research, University of California, 1989), 2-38.

Atilio Petruccioli, "The Courtyard House: Typological variations over space and time," in: Courtyard Housing: Past, Present and Future, edited by Edwards Brian, Magda Sibley, Mohammad Hakmi and Peter Land (USA: Taylor and Francis, 2005), 2-26. 
Maria Philokyprou, Building Materials and structures in the Architecture of Ancient Cyprus, PhD thesis, Department of Archaeology, University of Cyprus, 1998.

Abdelsalam Aldawoud, "Thermal Performance of Courtyard Buildings," Energy and Buildings 40, no. 5 (2008): 906-910.

Francesca De Filippi, "Traditional architecture in the Dakhleh Oasis, Egypt: space, form and building systems," in: Plea 2006, Geneva, 6-8 September 2006.

Maria Philokyprou and Aimilios Michael, "Evaluation of the Environmental Features of Vernacular Architecture. A Case Study in Cyprus," in: Proceedings of the 4th International EuroMediterranean Conference on Cultural Heritage (EuroMed 2012), Limassol, Cyprus, 29 October - 3 November 2012, 349-354.

Amir Hosein Ghaffarian Hoseini, Umberto Berardi, Nur Dalilah Dahlan, and Ali GhaffarianHoseini. "What can we Learn from Malay Vernacular Houses?" Sustainable Cities and Society 13, (10, 2014): 157-170.

Susanne Bodach, Werner Lang, and Johannes Hamhaber. "Climate Responsive Building Design Strategies of Vernacular Architecture in Nepal," Energy and Buildings 81, no. 0 (10, 2014): 227 242 .

Aimilios Michael, The bioclimatic dimension in the work of Neoptolemos Michaelides, Research Project, National Technical University of Athens, 2003.

Marios Economides, The relationship between modern and traditional in the work of the architect Neoptolemos Michaelides, Research Project, Architectural Association, Nicosia, 1992.

Stefanos Sinos, Review of the Vernacular Architecture of Cyprus (Athens: I. Makris A.E., 1976).

Demi, Danilo, ed., The Walled City of Nicosia, A Typology Study (Nicosia: UNDP United Nations Development Programme, 1997).

Amos Rapoport, "Vernacular Design as a model system in Vernacular Architecture," in: The Vernacular Architecture in the Twenty-First Century: Theory Education and Practice, edited by Lindsay Asquith and Marcel Vellinga (England: Taylor and Francis, 2006), 179-198. Chip Sullivan, Garden and Climate (New York: McGraw-Hill, 2002).

Rapoport, Vernacular Design as a model system in Vernacular Architecture, 179-198.

Das, Courtyards Houses of Kolkata: Bioclimatic, Typological and Socio-Cultural Study.

Rapoport, Vernacular Design as a model system in Vernacular Architecture, 179-198.

Ibid.

George H. Papacharalambous, The Cypriot House, Publications of the Cyprus Research Centre XXIX (Nicosia: Theopress Ltd., 2001).

Ioannis Ionas, La Maisone Rurale de Chypre. (XVII-XXe siècle). Aspects et Techniques de Construction, Nicosie, (Nicosia: Publications of the Science Research Centre, 1988).

Philokyprou and Michael, Evaluation of the Environmental Features of Vernacular Architecture. A Case Study in Cyprus, 349-354.

Ibid, 349-354.

Ibid, 349-354.

John R. Goulding, J. Owen Lewis, Theo C. Steemers, Energy in Architecture: The European Passive Solar Handbook, (London: BT Batsford Ltd., 1993).

Victor Olgyay, Design with Climate, Bioclimatic Approach to Architectural Regionalism (New York: Princeton, 1963).

Goulding, Lewis and Steemers, Energy in Architecture: The European Passive Solar Handbook.

Maria Philokyprou and Aimilios Michael, "The Contribution of the Courtyard to the Environmental Perception of Residential Architecture in Cyprus," in: 4th International Conference Renewable Energy Sources \& Energy Efficiency, New Challenges, edited by Ioannis Michaelides, Agis Papadopoulos and Andreas Poullikkas, Nicosia, Cyprus, 06- 07 June 2013, 166-177.

Maria Philokyprou, Amilios Michael, Andeas Savvides and Eleni Malaktou. "Examination and Assessment of the Environmental Characteristics of Vernacular Rural Settlements in Varying Topographies in Cyprus", in International Conference on Sustainable Buildings 2014 (WSB'14), Barcelona, 23-28 October, 2014, pp. 494-501. 
Aldawoud, Abdelsalam. “Thermal Performance of Courtyard Buildings.” Energy and Buildings 40, no. 5 (2008): 906-910. doi: http://dx.doi.org/10.1016/j.enbuild.2007.07.007.

Bodach, Susanne; Lang, Werner and Hamhaber, Johannes. "Climate Responsive Building Design Strategies of Vernacular Architecture in Nepal." Energy and Buildings 81, no. 0 (10, 2014): 227242. doi: http://dx.doi.org/10.1016/j.enbuild.2014.06.022.

Danilo, Demi. The Walled City of Nicosia, A Typology Study. Nicosia: UNDP United Nations Development Programme, 1997.

Das, Nibedita. Courtyards Houses of Kolkata: Bioclimatic, Typological and Socio-Cultural Study. Master of Architecture, Department of Architecture College of Architecture, Planning and Design, Kansas State University, Manhattan, Kansas, 2006.

De Filippi, Francesca. "Traditional architecture in the Dakhleh Oasis, Egypt: space, form and building systems." Plea 2006, Geneva, 6-8 September 2006, 1-6.

Economides, Marios. The relationship between modern and traditional in the work of the architect Neoptolemos Michaelides. Research Project, Architectural Association, Nicosia, 1992.

Ghaffarian, Hoseini; Amir, Hosein; Berardi, Umberto; Dalilah, Nur Dahlan and Ghaffarian Hoseini, Ali. "What can we Learn from Malay Vernacular Houses?" Sustainable Cities and Society 13, (10, 2014): 157-170. doi: http://dx.doi.org/10.1016/j.scs.2014.04.008.

Goulding, R. John; Lewis, J. Owen; Steemers, C. Theo, Energy in Architecture: The European Passive Solar Handbook. London: BT Batsford Ltd., 1993.

Hinrichs, Craig. "The Courtyard Housing Form as Traditional Dwelling." In The Courtyard as dwelling, Traditional Dwellings and Settlements Working Paper Series, Volume six, IASTE, WP06-89. Berkeley: Center for Environmental Design Research, University of California, 1989, $2-38$.

Ionas, Ioannis. La Maisone Rurale de Chypre. (XVII-XXe siècle). Aspects et Techniques de Construction, Nicosie. Nicosia: Publications of the Science Research Centre, 1988.

John S. Reynolds, ed. Courtyards: Aesthetic, Social and Thermal Delight. New York: John Wiley, 2002.

Michael, Aimilios. The bioclimatic dimension in the work of Neoptolemos Michaelides. Research Project, National Technical University of Athens, 2003.

Özkan, Suha. "Foreword -Courtyard: A Typology that Symbolizes Culture." In Courtyard Housing: Past, Present and Future, edited by Edwards Brian, Magda Sibley, Mohammad Hakmi and Peter Land. USA: Taylor and Francis, 2005, xiv-xvi.

Oliver, Paul. Dwellings. The house across the world. (Oxford: Phaidon Press Ltd., 1987)

Olgyay, Victor. Design with Climate, Bioclimatic Approach to Architectural Regionalism. New York: Princeton, 1963.

Papacharalambous, George. The Cypriot House. Publications of the Cyprus Research Centre XXIX, Nicosia: Theopress Ltd., 2001.

Petruccioli, Atilio. "The Courtyard House: Typological variations over space and time." In Courtyard Housing: Past, Present and Future, edited by Edwards Brian, Magda Sibley, Mohammad Hakmi and Peter Land. USA: Taylor and Francis, 2005, 2-26.

Philokyprou, Maria. Building Materials and structures in the Architecture of Ancient Cyprus. $\mathrm{PhD}$ thesis, Department of Archaeology, University of Cyprus, 1998.

Philokyprou, Maria; Michael, Amilios; Savvides, Andeas and Malaktou, Eleni. "Examination and Assessment of the Environmental Characteristics of Vernacular Rural Settlements in Varying Topographies in Cyprus.” In International Conference on Sustainable Buildings 2014 (WSB'14), Barcelona, 23-28 October, 2014. p.p. 494-501

Philokyprou, Maria and Michael, Aimilios. "The Contribution of the Courtyard to the Environmental Perception of Residential Architecture in Cyprus." In 4th International Conference Renewable Energy Sources \& Energy Efficiency, New Challenges, edited by Ioannis Michaelides, Agis Papadopoulos and Andreas Poullikkas, Nicosia, Cyprus, 06- 07 June 2013, pp.166-177. 
Philokyprou, Maria and Michael, Aimilios. "Evaluation of the Environmental Features of Vernacular Architecture. A Case Study in Cyprus." Proceedings of the 4th International Euro-Mediterranean Conference on Cultural Heritage (EuroMed 2012), Limassol, Cyprus, 29 October - 3 November 2012, pp.349-354.

Rapoport, Amos. "Vernacular Design as a model system in Vernacular Architecture." In The Vernacular Architecture in the Twenty-First Century: Theory Education and Practice, edited by Lindsay Asquith and Marcel Vellinga, England: Taylor and Francis, 2006, pp. 179-198

Sinos, Stefanos. Review of the Vernacular Architecture of Cyprus, Athens: I. Makris A.E., 1976 Sullivan, Chip. Garden and Climate. New York: McGraw-Hill, 2002.

Yannas, Simos. Solar Energy and Housing Design. Vols 1 \& 2, London: AA Publications, 1994 